\title{
Social Impact Management Assessment of Urban Flood is important- especially in Surabaya-Wonokromo and Surabaya-Brangkal
}

\author{
Soleh $^{1}$, Mohammad Sofyan ${ }^{2}$ \\ ${ }^{1}$ Faculty of Social and Political Sciences, Wiralodra University \\ ${ }^{2}$ Faculty of Administrative Sciences STIAMI Institute of Social Sciences and Management \\ soleh_hs@yahoo.com
}

Submitted: February $19^{\text {th }}, 2020$

Revised: March $12^{\text {th }}, 2020$

Published: March 30 $0^{\text {th, }} 2020$

\begin{abstract}
social assessment is a process that ensures that the execution of action reasonably informed and considered the critical social issues that are relevant, as well as providing a participation strategy for involving stakeholders at large. Socialization and Enforcement of laws and regulations related to particularly riverside following the normalization of physical development plan/development Wonokromo River flood control infrastructure and Brangkal should use a local culture aligned with the socio-economic, gender, and education of local people issues social surfaced in every area of study and assessment of the following community expectations and their advice on the results of the social assessment. In light of this, it expected that pre-construction, construction, and post-construction could be well supported by social security by the carrier the benefit of both the public, private, and government.
\end{abstract}

Keywords: Social Impact Assessment, River Flood Control, Social Security

\section{INTRODUCTION}

Social Impact Management Assessment of Urban Flood is important-especially in Surabaya-Wonokromo and Surabaya-Brangkals a pilot project due to several factors. Firstly, the results of studies on the Surabaya-Wonokromo (2005), Surabaya-Brangkal (2009) analysis of the environmental and social impact does not provide comprehensive information from the perspective of the stakeholders, especially the direct beneficiaries of the effects of urban flood control program both women and men. The final report in-depth study Wonokromo River at urabaya East Java (2005), states that the condition of the river many times Wonokromo changes the basic profile and cross-section of the river. This happens in the establishment of many illegal buildings along the river and border in addition to changes in DAS utilization. As a result, there was: (1) the increasing intensity with increasing flood runoff coefficient due to changes in land use in the upstream and downstream, thus tamping river capacity is exceeded, especially along with the discharge from the upstream tidal Wonokromo River, which is sodetan Brantas will receive the discharge increases; (2) increasing risk of flooding and complicate operations and maintenance of the river due to the density of building on flood plains and river border; and (3) Utilization Wonokromo river which is not following its function.

Efforts to repair the embankment made to address the above issues, there are still many obstacles, plaster awoke unable to withstand the pressure of typical ground avalanche the bend area. 
Social Impact Management Assessment of Urban Flood is important-especially in Surabaya-Wonokromo and Surabaya-Brangkal

Soleh, Sofyan

The concepts and theories used to analyze the data are the cycle of flood and flood control physical development, community participation, policies and activities, the theory conflict Chambell models, and theories of the Third-Party Intervention Model.

In-Law No. 24 the Year 2007 on Disaster Management, chapter 1 revealed that:

1. A disaster is an event or a series of events that threaten and disrupt the lives and livelihoods caused by both natural factors and factors non-skirt and human factors that lead to the emergence of human casualties, environmental damage, loss of property, and psychological impact.

2. A natural disaster is a disaster caused by the event or series of events caused by nature, which include earthquakes, tsunamis, volcanic eruptions, floods, droughts, hurricanes, and landslides.

Referring to Article 1, paragraph (2) above, considered a flood disaster. There are three stages of the cycle of flood prevention. Firstly, before the flood prevention phase. Secondly, the handling time of the flood. Third, post-flood recovery phase. The physical construction of flood control programs included in the first phase of the flood control cycle. It is in line with article 47, paragraph (2) point b, Act No. 7 of 2008, as follows:

\section{Article 47}

(1) Mitigation as referred to in Article 44 letter $\mathrm{c}$ to reduce disaster risk for the people who are in disaster-prone areas.

(2) Mitigation activities referred to in paragraph (1) is done through:

a. The implementation of spatial planning;

b. Setting development, infrastructure development, urban design, and

c. Providing education, counseling, and training, both conventional and modern.

One of the Presidential Instruction No. 4 of 2012 on Disaster Flood and Landslide is encouraging community participation. Community participation is a technical process to provide opportunity and authority to the broader community to jointly solve problems in general, especially in the context of control flooding in both physical and non-physical development of flood control - the division of authority based on the level of participation community in these activities. Public participation aims to find better solutions to problems in the community by opening up more opportunities for people to participate in contributing both to the pre-construction phase, construction phase, and post-construction of flood control disk. The implementation of it is expecting to run safely, more productive, efficient, and sustainable social security backed by the carrier interests in society (stakeholders).

Stakeholder flood generally grouped into three parts. (1) the beneficiaries, the people who benefit/impact directly or indirectly; (2) intermediaries, community groups, or individuals who can provide or facilitate the consideration of flood prevention, among others: consultants, experts, NGOs, and professionals in the field of natural resources; and (3) decision/policymakers, agencies/institutions authorized to make such decisions and legal basis government agencies and water resource board. Community participation of the third section is a form of accountability for the implementation of government programs, in general, especially in the physical construction of flood control. In other words, government accountability can be assessed from the extent of public participation and related parties (stakeholders) other development programs - the public participation activities conducted from the conception phase, construction, operation-maintenance, and evaluation and monitoring. Referring to 
Social Impact Management Assessment of Urban Flood is important-especially in Surabaya-Wonokromo and Surabaya-Brangkal

Soleh, Sofyan

Narayan and McCracken (1998, p. 63-77), and a determination made by the method of sorting stakeholders Stakeholders Analysis. Stakeholder analysis conducted by 4 (four) stages of the process, namely: (a) identification of stakeholders, (b) assessment of stakeholder interest in the flood response activities, (c) the evaluation of the influence and benefits of each stakeholder, and (d) the formulation of a strategic plan stakeholder participation in flood control in all phases of activity. All processing is done by promoting the learning activities and increase the potential for the community to actively participate, as well as providing an opportunity to take part and have decision-making authority in prose and resource allocation in the flood response activities. Regarding the World Bank (1994) and Zonneveld (2001), The level of community participation in flood management activities consist of 7 (seven) levels based on the mechanism of interaction, namely: (i) Rejection (resistance/Opposition); (ii) Exchange of information (informationsharing); (iii) Consultation (consultation with no commitment); (iv) Consensus and Decision Memorandum of Understanding (consensus-building and agreement); (v) Collaboration (collaboration); (vi) the risk-sharing Empowerment (empowerment-risk sharing); and (vii) Empowerment and Partnership (empowerment and partnership).

Policies are related to public participation with flood prevention regulated in Presidential Instruction No. 4 of 2012 on Disaster Flood and Landslide. Besides, also regulated in Government Regulation No. 38 the Year 2011 on the river.

Presidential Instruction No. 4 of 2012 on Disaster Flood and Landslide assigned to the 18 agencies at the central and regional level to coordinate and conduct response actions floods and landslides and to encourage public participation following businesses to engage in such activities. This BOTH instructed on the point (1) and (2) in the following Instruction: "TWO: 1) Perform coordination and cooperation to implement flood prevention and soil avalanche.2) Increasing the participation of communities and businesses to flood prevention activities and landslides ". The third section reviews that one of the duties of the Minister of Public Works is constructing flood control infrastructure. For more details, see the following quote:

Minister of Public Works:

a. Prepare and disseminate maps flood-prone communities;

b. Monitoring of river water levels and give early warning of the dangers of flooding;

c. Make efforts to mobilize human resources, facilities and infrastructure disaster floods and landslides standards prescribed;

d. Assist authorities in their efforts to disaster management floods and landslides.

Besides, the task of governors/ regents/mayors following allocate such coordination and cooperation among the provinces/districts/cities, as mentioned in clause (e) and (f). Government Regulation No. 38 the Year 2011 on the River specifically governing living river, river management, licensing streams, and empowerment and is individually listed in article 2 of the following, "This government regulation governing the River Room, river management, licensing information systems, and community empowerment. "

Meanwhile, the chapter regulating rivers and riparian specially arranged in sections 5 and 16 the following:

Article 5

(1) The stream consists of:

a. the riverbed, and 
Social Impact Management Assessment of Urban Flood is important-especially in Surabaya-Wonokromo and Surabaya-Brangkal

Soleh, Sofyan

b. river border.

(5) Border rivers referred to in paragraph (1) letter b serves as a buffer between the river ecosystem and the mainland so that the function of the river and human activities are not mutually disturbed

Article 16

(3) In determining the demarcation line should consider the geomorphological characteristics of the river, the local social and cultural conditions, and concerning the access to equipment, materials, and human resources to operate and maintenance of the river.

The articles are arranged such flood risk reduction provided for in Article 35-38 and 47, the following

Article 36

(1) Scale flood risk reduction as referred to in Article 35 paragraph (2) letter a with construct:

a. Flood control infrastructure, and

b. Infrastructure control runoff.

(2) Construction of flood control infrastructure referred to in paragraph (1) letter a to create:

a. Increasing the capacity of the river;

b. Dike;

c. Flood spillway and pump;

d. Embankments, and

e. Urban drainage.

(3) Developing infrastructure controlling runoff referred to in paragraph (1) letter b done by creating:

a. Water infiltration, and

b. Reservoir flooding.

Article 37

(1) Watersheds, as referred to in Article 36 paragraph (3) a letter similar to the channel, perforated pipes, wells, ponds recharge and infiltration fields according to soil conditions and the depth of the water table.

(2) In terms of catchment areas referred to in paragraph (1), be used for other purposes, shall use a cover layer or pavement to pass water.

Article 38

(1) Construction of reservoir flood referred to in Article 36 paragraph (3) letter b must be connected with the river.

(2) In terms of reservoir flood as described in section (1) built on a right land individual or legal entity, its implementation must be conducted following the provisions of the legislation inland.

Article 47 
Social Impact Management Assessment of Urban Flood is important-especially in Surabaya-Wonokromo and Surabaya-Brangkal

Soleh, Sofyan

(1) Recovery after the floods referred to in Article 41 paragraph (2) letter $\mathrm{f}$ made by the Government, provincial governments, and district/city within their authority through rehabilitation and reconstruction.

(2) Rehabilitation and reconstruction activities referred to in paragraph (1) to restore the environment, public facility, social facilities, and infrastructure river.

The formulation of the type and level of participation will vary depending on the types of policies or activities. Facilitate identification of nature and level participation community in the World Bank's policies or actions as reviewed by Narayan \& McCraken (1998, pp. 24-25). The social assessment generally classifies 4 (four) types of systems or activities. First, the Indirect benefits, direct social cost, that is a policy or activity provide indirect benefits to the community but the social cost. Examples of these activities include the development of infrastructure, biodiversity, structural adjustment, and privatization. Second, Significant uncertainty or risk, which is a policy to complete issues that form the solution is not clear and is not reasonably available information and commitment of the target group. Examples of these activities include intervention / post-conflict development. Thirdly, a Large number of beneficiaries and few social costs, that's one policy or actions that the number of recipients or impact is a substantial but only little social cost. Examples of these activities include the development of health, education, agricultural extension, and decentralization. Fourth, Targeted assistance, which is a policy or group activity, and the number of beneficiaries or impact, has been clearly defined. Examples of these activities, among others, to reduce poverty in the region, handling refugees, institutional reforms (institutional reform), and victims of natural disasters.

By looking across all four types of policies/activities are grouped by the World Bank, sub physical construction of flood control projects in Surabaya and Surabaya-Wonokromo-Brangkal including the types of systems and events of the first, namely Indirect benefits, direct social cost, that is a policy or activity provide indirect benefits to the community but the social cost. Although the physical construction of flood control benefits to society, as a policy/activity is usually not initiated regardless of the pros and cons between stakeholder interests associated with each. Therefore, it takes a unique analysis tool to dissect the problem. The theoretical conflict model developed by Campbell appropriately used to analyze the issues mentioned above.

\section{METHOD}

The approach used in the social assessment is quantitative and qualitative. Elections lie within a study and survey respondents, focus groups, and interviews using purposive sampling. The reason, the location of the study is known. Social assessment activities carried out by collecting data and information about legislation, other policy documents, research results, and policy of the existing flood control. Besides, the household survey conducted on 50 households, Focus Group discussion (FGD) for community groups, 10 were women, and ten were female. Besides brief and focused interviews with respondents from the following elements: (1) government (decision/policymakers), (2) professional (intermediaries), (3) the general public (beneficiaries).

Implementation of the assessment carried out in the village, specifically Wonorejo and Medokan Semampir, for Surabaya-Wonokromo samples. Both communities are located on the left and right Wonokromo and Urban Warrior River and Village Sooko Kulon samples for the 
Social Impact Management Assessment of Urban Flood is important-especially in Surabaya-Wonokromo and Surabaya-Brangkal

Soleh, Sofyan

Surabaya-Brangkal region. They are located on the left and right as well as the Brangkal River. The four areas include the areas to be affected by the construction of flood control physical development.

\section{RESULT AND DISCUSSION}

Surabaya and Mojokerto never experienced flooding, and one of them is closely related to the presence of Wonokromo to Surabaya River and River Brangkal for the City / County Mojokerto.

The final report comprehensive study Kali River Wonokromo Surabaya East Java (2005) states that the condition of the river many times Wonokromo changes the basic profile and cross-section of the river. It happens due to the establishment of many illegal buildings along the river and the border in addition to the change in DAS utilization.

The increasing intensity of flooding in line with the increase in the coefficient of run-off to changes in land use in the upstream and downstream, so the capacity is exceeded tamping river, especially along with the discharge from the upstream tidal Wonokromo river, which is sodetan Brantas will receive the discharge increases. Increased risk of flooding and complicate operations and maintenance of the river due to the density of building on flood plains and river border. Utilization Wonokromo Kali river, which is not following its function. Efforts to repair the embankment made to address the above issues, there are still many obstacles, plaster awoke unable to withstand the pressure of typical ground avalanche the bend area.

Research results Nurdiyanto \& Fauzi in Planning Normalization and Levee Improvement District Mojokerto Brangkal Kali (2009) states that Brangkal time has an essential role in economic and agricultural activities Mojokerto with rain catchment area $128.67 \mathrm{KM}$ with rice production 6 tonnes/ha. In February 2004, the excess discharge along the Kali Brangkal, causing flooding in the area Mojokerto and disrupt economic activity.

Based on survey results, the excess water discharge was caused by Cross-sections, mainly in the upstream is not able to accommodate the flow of water due to changes in land use. Refinement river flows occur in the headwaters area or a specific place.

Local Government in Surabaya and Mojokerto been trying to solve the flooding problem by using a structural and non-structural. The architectural approach to flood control through physical development. The physical structure of existing flood control in the study area, in particular, sub-Wonokromo Surabaya projects, particularly in urban Wonorejo are (1) pump house, (2) Jagir Dam, (3) Parapet, (4) Dike, (5) Sheet Pile, (6) Sandbag. The drainage in the Village Medokan Semampir is (1) pump house, (2) Jagir Dam, (3) Parapet, (4) dike, and (5) drainage. Meanwhile, the physical building of existing flood control projects in sub-Brangkal Surabaya, especially in urban and village Sooko and Prajurit Kulon, are (1) weir, (2) parapet, (3) levees, (4) drainage. Early Warning System in Mojokerto is a non-structural effort in addition to the Flood Preparedness Guidelines: Watershed (DAS) Brantas Year 2011-2012. Meanwhile, it is not in the study area in the city of Surabaya.

Critical issues related to the physical structure of existing flood control disaggregated into four sections, namely, (1) physical development planning flood control has not been comprehensive and integrative along the river sub-projects, (2) quality of the physical plant is still found there were not good: (3) a sense of community ownership over the embankment and river border follows the river is still not right, (4) which has not been good coordination between 
Social Impact Management Assessment of Urban Flood is important-especially in Surabaya-Wonokromo and Surabaya-Brangkal

Soleh, Sofyan

agencies, private, Government and the community to operation and maintenance of the physical plant control flooding along the river.

Assessment of communities in the study of the physical development plan of flood control projects in both sub-Wonokromo Surabaya and Surabaya-Brangkal was 98.9\% disagreed, and 1.1\% did not answer. All respondents in the household survey agree $100 \%$ better in the Village Medokan Semampir, Pvt Kulon, and Sooko, except Sub Wonorejo, only 95.1\%. Similarly, the same percentage of their attitude to the physical development plan of flood control only has specific requirements. They have to relocate are (1)the compensation is not detrimental to the community, (2)damages in the form of the return and relocation sites are located in the local area because it would disrupt the livelihoods of the following levels mobilize them to work or to public facilities and another social service.

Although respondents were surveyed and FGD participants agreed on a plan of flood control, physical development but is expected to appear critical issues that need to be dealt with in a serious and thoughtful both sub-projects Surabaya Wonokromo and Sub-Brangkal project. Significant issues raised are predicted to be associated with land acquisition.

Social and economic problems that are predicted to surface, especially in the four areas of study and will possibly occur in other regions is about: (1) land acquisition, compensation and relocation especially for RW 07, RT 01-04 in the village of Wonorejo, RW 08 in the village of Medokan Semampir, as well as 1-8 in the Sooko village, whereas in the Village of Prajurit Kulon relatively safe. (2) waste management has not arranged either along a stream, and Wonokromo river-related Brangkal awareness, both those who live upstream or downstream in the middle. (3) coordination among related institutions following the administration area in flood control is still not right. (4) Lack of socialization and enforcement river of laws and regulations, particularly those related to the river border.

\section{CONCLUSION}

Institutions involved in the physical construction of the sub-projects in SurabayaWonokromo and Surabaya-Brangkal that: (1) physical development planning so a comprehensive flood control along the river and integrated sub-projects; (2) physical building flood control should be good quality; (3) Socializing, facilitation, and assistance to the community that people have a sense of ownership and responsibility for the levee and river border follows the river to take care of the physical structure of existing flood control and household waste into the river; and (4) communication and coordination among agencies, private, Government and the community to physical plant operations and maintenance of flood control along the river for the better. Four things need to has done regarding the application of the principles of good governance: transparent, accountable, and participatory, as well as considering the values of local wisdom.

To manage the critical issues that are predicted to exist at the pre-construction, construction, and post-construction, the stakeholders involved in the physical structure of a flood control plan should make social engineering in the pre-construction, construction, and post-construction supported with its budget. It is necessary to pay attention to suggestions and hope that the local physical development plan of flood control following political, socioeconomic, and cultural communities based on gender and age. It needs to be a basis for making 
Social Impact Management Assessment of Urban Flood is important-especially in Surabaya-Wonokromo and Surabaya-Brangkal

Soleh, Sofyan

an effective communication strategy that the implementation of pre-construction, construction, and post-construction can be safe.

Socialization and Enforcement of laws and regulations related to particularly riverside following the normalization of physical development plan/development Wonokromo River flood control infrastructure and Brangkal should use a local culture aligned with the socioeconomic, gender, and education of local people issues social surfaced in every area of study and assessment of the following community expectations and their advice on the results of the social assessment. In light of this, it is expected that pre-construction, construction, and postconstruction can be well supported by social security by the carrier the benefit of both the public, private, and Government.

\section{REFERENCE}

Center For Good Governance. (2006). A Comprehensive Guide for Social Impact Assessment.

Creswell, J. W. (2003). Research Design: Qualitative, Quantitative, and Mixed Methods Approaches (2nd ed.). London: SAGE Publications.

Nurdiyanto, \& Fauzi, A. (2009). Planning Normalization and Levee Improvement District Brangkal Kali Mojokerto. Surabaya: Surabaya Institute of Technology.

Perum Jasa Tirta 1 (2011). Flood Preparedness Guidelines: Watershed (DAS) Brantas Year 2011-2012. Surabaya: Surabaya.

Rietbergen, M.-J., \& Narayan, D. (1998). Participation and Social Assessment: Tools and Techniques. Washington: The World Bank.

Sea Defence Consultants. (2009). Aceh Nias Sea Defence Flood Protection, Escape, and Early Warning Project. "Flood Risk Management: A Manual for Government Action Plan Aceh. Sea Defence Consultants.

Sofyan, M. (2016). Analisa Kepuasan Masyarakat Kota Dan Kabupaten Mojokerto Terhadap Proyek Pengendalian Banjir Perkotaan Dengan Metode Importance Performance Analysis. Eksekutif, 13(2), 320-329. Diambil kembali dari http://jurnal.ibmt.ac.id/index.php/jeksekutif/article/view/121/pdf

Sofyan, M. (2019). Community Satisfaction of the Urban Flood Control System Improvement Project (UFCSI). Ilomata International Journal of Social Science, 1(1), 29-34. Diambil kembali dari https://www.ilomata.org/index.php/ijss/article/view/36/35

The World Bank. (1994). The World Bank and Participation. Washington DC: World Bank. Diambil kembali dari http://documents.worldbank.org/curated/en/627501467990056231/TheWorld-Bank-and-Participation

Zonneveld, L. (2001). The Toolkit for Participation in Local Government Learning to Make participation Work. Oxfam/Novib. 